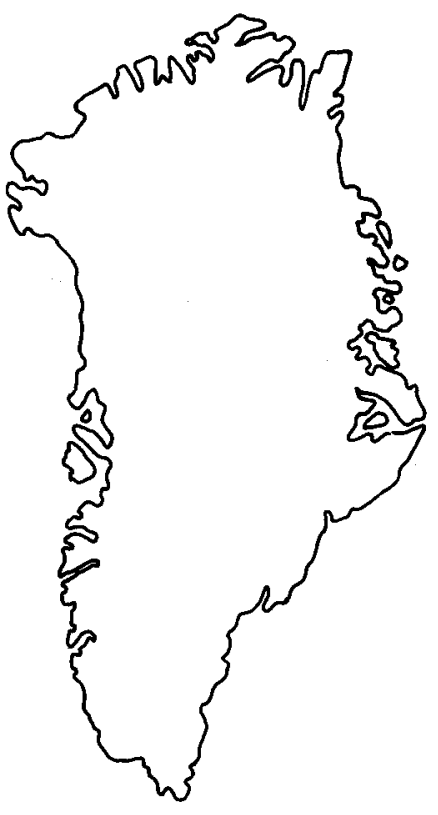

\title{
A Silurian trilobite fauna dominated by Calymene from Kap Tyson, Hall Land, western North Greenland
}

\author{
Philip D. Lane and Derek J. Siveter
}

\begin{abstract}
The Silurian trilobites described here are referred to 5 genera and 5 species-level taxa of which Calymene iladon is new. The composition of the fauna is unusual for North Greenland in that it is overwhelmingly dominated by specimens of Calymene. Other elements of the fauna are known from other areas of North Greenland, and at least closely related forms of one of them have cosmopolitan distributions.

P. D. Lane, Department of Geology, University of Keele, Keele, Staffordshire, ST5 $5 B G, U . K$

D. J. Siveter, University Museum, Parks Rd., Oxford, OX1 3PW, U.K.
\end{abstract}

The trilobites described in this paper were collected in western North Greenland by M. Sønderholm during 1985, from the flanks of a carbonate mound on the tip of Kap Tyson (Fig. 1), within the Offley Island Formation (Hurst, 1980); they are therefore of late Llandovery age. A summary of the geology of Hall Land, including the biostratigraphic setting, was given by Dawes \& Peel (1984).

In described trilobite faunas from the Silurian platform carbonates of North Greenland (Lane, 1972, 1979, 1984, 1988; Lane \& Peel, 1980; Lane et al., 1980; Lane \& Owens, 1982), and in collections scanned but not yet described (P. D. Lane, unpublished reports to Grønlands Geologiske Undersøgelse, 1980, 1986) calymenid trilobites are very rare and always disarticulated. In the present collections of some 90 specimens, Calymene iladon sp. nov. accounts for all but seven specimens, and its remains are substantially articulated.

\section{Systematic descriptions}

All specimens are from GGU sample 301925. Type and figured specimens (MGUH prefix) are deposited in the Geological Museum, Copenhagen.

Family Styginidae Vogdes, 1890

(emend. Lane \& Thomas, 1983)

\section{Genus Bumastus Murchison, 1839}

Type species. Bumastus Barriensis Murchison, 1839 from the Barr Limestone Member of the Coalbrookdale
Formation, Wenlock Series, Silurian; West Midlands, U.K.

\section{Bumastus sp.}

Fig. 2e

Figured material. MGUH 19510 (fragmentary cranidium from GGU 301925).

Discussion. A single fragmentary cranidium is best referred to Bumastus. Although it displays a sculpture of densely-spaced small pits like that of material from the Wenlock of Kronprins Christian Land, eastern North Greenland referred to 'goldillaenid gen. et sp. indet. 2' by Lane $(1972$, p. 347 , pl. 62 , fig. 14) it displays the characteristic broadly oval, exsagittally elongate $1 \mathrm{~g}$ glabellar muscle impression placed at about $150 \%$ of its own length from the posterior cranidial border shown by species of the genus (Lane \& Thomas, 1978, pl. 1, fig. 5).

\section{Genus Ekwanoscutellum Přibyl \& Vaněk, 1971}

Type species. Bronteus ekwanensis Whiteaves, 1904 from the late Llandovery of Ontario, Canada.

\section{?Ekwanoscutellum $\mathrm{sp}$. \\ Fig. 2d}

Figured material. MGUH 19511 (fragmentary cranidium from GGU 301925). 


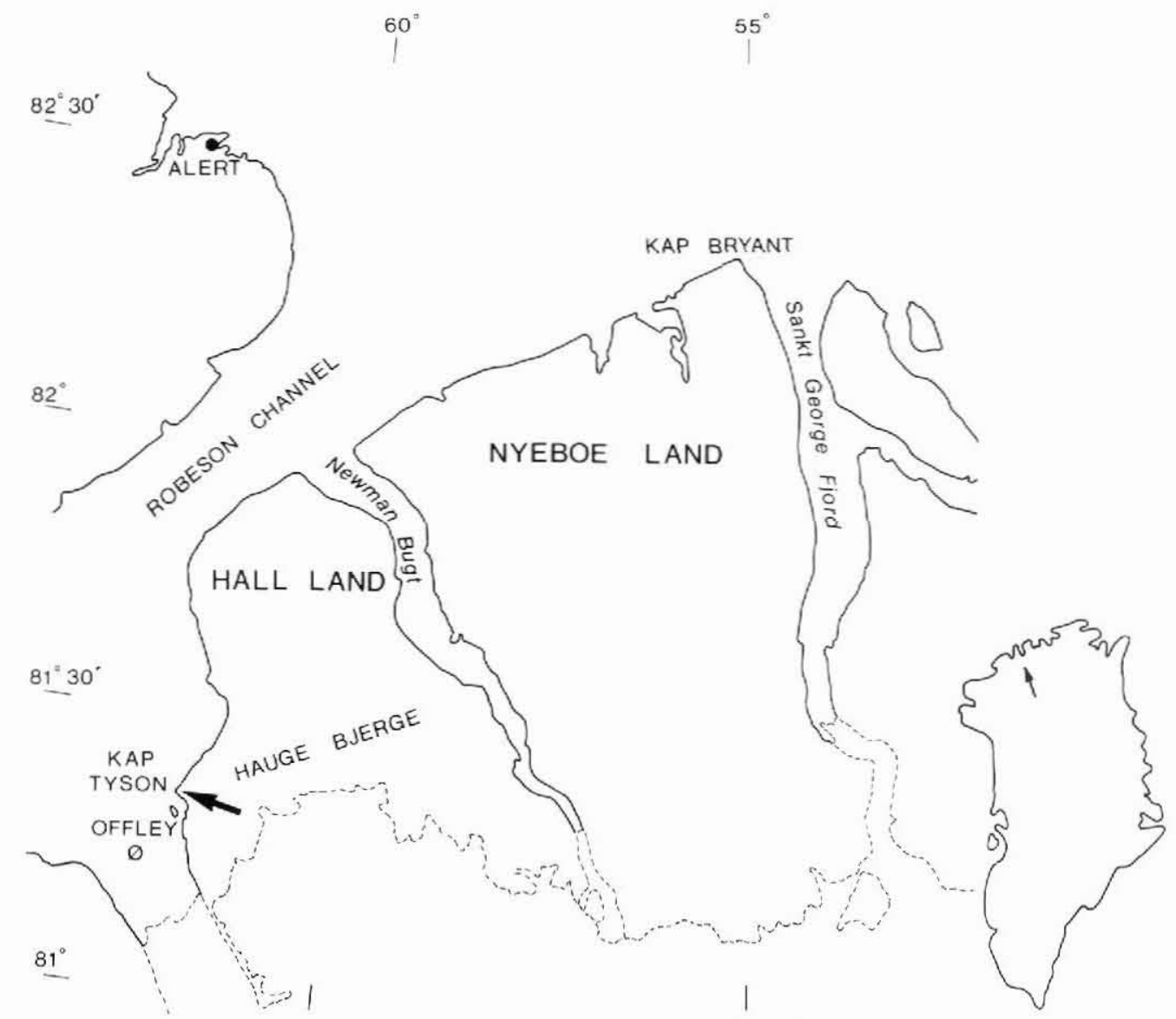

Fig. 1. Western North Greenland showing the collection locality for GGU 301925.

Discussion. A solitary cranidial fragment shows a complete anterior border furrow which thus excludes assignation to Opoa, Meroperix or Kosovopeltis. The anterior border, however, has some resemblance to that of Ekwanoscutellum (see E. ekwanensis figured by Norford 1981, pl. 2, figs 2,4) in that it becomes higher and arches upwards sagittally. Without confidence, therefore, we assign it to that genus.

\section{Genus Kosovopeltis Šnajdr, 1958}

Type species. Kosovopeltis svobodai Šnajdr, 1958, from the Ludlow of Czechoslovakia.

\section{Kosovopeltis allaarti Lane, 1984}

Figs 2a-c

Figured material. MGUH 19512 (pygidium with 8 articulated thoracic segments); MGUH 19513-4 (pygidia); all from GGU 301925.
Discussion. The specimens agree well with the material figured by Lane (1984, pl. 1, figs 12, 14-16), from strata of possible Wenlock age from Kayser Bjerg, Hall Land.

In his discussion when establishing the species Lane noted its great similarity, especially in the morphology of the cranidium and the slit-like glabellar furrows, to K. tchernychevae Šnajdr, 1960 from an undefined Silurian horizon on the River Vagran, Urals, U.S.S.R. Very similar, if not conspecific, taxa form a species-group of Silurian age also in other parts of Europe, south-east Asia and Australia.

From the type Llandovery area, Wales, a single small complete specimen (which is referable to $K$. cf. $K$. allaarti; United States National Museum no. 443732) is known from the Rhydings Formation (Monograptus sedgwickii Biozone; Aeronian Stage; mid Llandovery). Kosovopeltis sp. aff. K. allaarti of Siveter (1989, p. 114) is from the late Wenlock or early Ludlow of south-west Ireland, and another close form from the Llandovery of the Oslo region, Norway, has been examined by one of the authors (P. D. L; unregistered specimen in Palaeontologisk Museum, Oslo). 

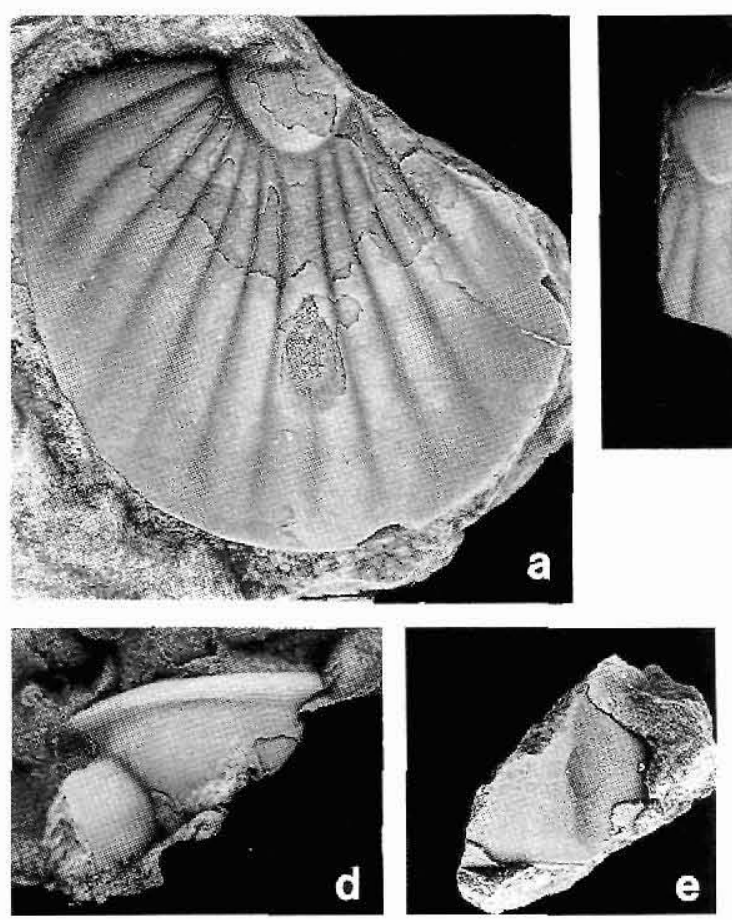

e

Fig. 2. a-c. Kosovopeltis allaarti Lane, 1984, MGUH 19512-4; 2 pygidia and pygidium with eight articulated thoracic segments, dorsal views. $\times 2, \times 1$ and $\times 4$ respectively. d. ?Ekwanoscutellum sp., MGUH 19511; fragmentary cranidium, dorsal view. $\times 3$. e. Bumastus sp., MGUH 19510; fragmentary cranidium, dorsal view. × 3. f, g. Meitanillaenus sp., MGUH 19515-6; partial thoraces and pygidia, dorsal views. $\times 4$.

In Honshu and Shikoku, Japan, what is very probably a single species of Kosovopeltis close to if not conspecific with allaarti has been described under seven species group designations - Microscutellum primigenium and Microscutellum sp. nov. (both Kobayashi \& Hamada, 1974); Japonoscutellum japonicum puteatum, Japanoscutellum japonicum laticephalum and 'Scutelloid gen. et sp. indet.' (all Kobayashi \& Hamada, 1986); and Kosovopeltis hidensis hidensis and Kosovopeltis hidensis striatum (both Kobayashi \& Hamada, 1987). Kosovopeltis jenkinsi (Etheridge \& Mitchell, 1890; see Chatterton \& Campbell (1980, p. 103, pl. 12, figs 1-9) who commented on its similarity to and possible conspecificity with K. tchernychevae) from the Ludlow of New South Wales, Australia, Kosovopeltis guangyuanensis Zhou \& Chen, 1975 from the Telychian of North Sichuan, People's Republic of China and probably 'Planiscutellum' niuchangensis Chang (1974, p. 175, pl. 80 , fig. 1) from the Silurian of south-west China are also at least closely related forms.
Genus Meitanillaenus Chang, 1974

Failleana Chatterton and Ludvigsen, 1976

Opsypharus Howells, 1982

Type species. Meitanillaenus binodosus Chang, 1974, from the Llandovery of Guizhou Province, People's Republic of China.

\section{Meitanillaenus sp.}

Figs $2 \mathrm{f}, \mathrm{g}$

Figured material. MGUH 19515-6 (pygidia, with 6 and 1 thoracic segments attached respectively from GGU 301925).

Discussion. The only other two non-calymenid trilobite fragments from the fauna may be referred to Meitanillaenus. The present specimens lack the clear paired muscle impressions and sagittal carina, morphological features which can vary in expression within a population (Lane \& Thomas, 1978, p. 16), compared to the pygidia described and figured as Opsypharus sp. by Lane (1984, p. 55, pl. 1, figs 5-8), also from possible Wenlock strata 
of Hall Land. The paired muscle impressions are present in the type species, but from Chang's illustration, the posterior outline of the pygidium is semicircular, as compared to subtriangular in the Greenland material. In addition, that material shows a less well-developed holcos anterolaterally where it is much narrower adjacent to the anterior border. The preservation in the two sets of material is, in any case, very different.

Family Calymenidae Milne Edwards, 1840 Subfamily Calymeninae Milne Edwards, 1840

\section{Genus Calymene Brongniart in Brongniart \& Desmarest, 1822}

Type species. Calymene blumenbachii Brongniart in Desmarest, 1817 (see Siveter, 1989, p. 128).

\section{Calymene iladon sp. nov.}

Plates 1, 2

Derivation of name. Greek 'in great abundance'.

Holotype. MGUH 19517 (cranidium).

Figured material. MGUH 19518-9 (cephala); MGUH 19520-3 (cranidia); MGUH 19524 (free cheek); MGUH 19525 (hypostome); MGUH 19526-8 (partial thoraces with articulated pygidia); MGUH 19529-30 (pygidia), all from GGU 301925.

Other material. GGU 301925.1-25 (cranidia); GGU 301925.26-40 (free cheeks); GGU 301925.41-43 (hypostomes); GGU 301925.44-58 (partial thoraces); GGU 301925.59-83 (pygidia).

Diagnosis. A species of Calymene combining the following characters: a relatively short preglabellar area which is $0.1-0.14$ times as long as the glabella; anterior border is a short, low, upturned rim; palpebral lobe forwardly positioned, mid-length centred on L3; hypostome with non-differentiated to extremely weakly raised macula situated in a sunken suboval area; pygidium with seven or eight axial rings and five or six pleural furrows.

Description. Cranidium is about 1.7 times as wide as it is long. Glabella is very weakly bell-shaped in outline and about $0.75-0.8$ times as wide as it is long. Occipital ring is slightly narrower (tr.) than the glabella at $\mathrm{L} 1$; in dorsal view it arches forward medially, and is gently to moderately convex in profile (sag.); abaxially it is very weakly inflated, and about 0.7 times as long (exsag.) as it is sagittally. Occipital furrow is moderately deep and
V-shaped medially, becoming much deeper and gradually narrows (exsag.) behind L1. The latter is subquadrate in outline and separated from central glabellar area by extremely weak, broad (tr.) posterior extension of $\mathrm{S} 1$. Within the adaxial fork of S1 there is a small, distinct intermediate lobe and the anterior branch of S1 runs anteriorly as a shallow depression over inner neck of $\mathrm{L} 2$ to connect with a well-incised S2. L2 is one-half to two-thirds the size of L1, abaxially it is papillate in outline, and directed outward and slightly forward, to contact with a short (tr.) buttress from the fixed cheek. L3 is distinctly inflated, about one-half the size of L2 and runs transversely down the side of the glabella. $S 3$ is well marked. Some specimens have a $\mathrm{L} 4$ and a very weak S4. Frontal lobe is about 0.8 times as wide as the glabella across L1, moderately to well-rounded in dorsal outline, projects moderately in front of the fixed cheeks. In lateral profile the glabella stands well above height of fixed cheek, is gently to moderately dorsally convex and falls only slightly in height from occipital furrow to frontal lobe; thereafter it is much more convex and descends more sharply to anterior face of frontal lobe which slopes downward and slightly backward to the preglabellar furrow. Axial furrow is naxrow and shallowest beside the occipital ring, deep and slightly crescent-shaped beside L1, slightly deeper and wider at S1, and interrupted at L2 by the contact of this lobe with the buttress from the fixed cheek; from S2 to the preglabellar furrow it is deep and narrow. The preglabellar furrow is short and of moderate depth sagittally; abaxially it becomes deeper. Between the anterior border and the fixed cheek the border furrow is equally short (exsag.) and slightly shallower than the sagittal depth of the preglabellar furrow. Anterior face of preglabellar furrow rises sharply for a short distance and passes smoothly into the dorsal surface of the anterior border

\section{Plate 1}

All specimens are from GGU sample 301925, Kap Tyson, Hall Land, western North Greenland.

Calymene iladon sp. nov.

Figs 1a-d, MGUH 19517; holotype cranidium, dorsal, frontal, left lateral and oblique left lateral views, $\times 4$. 2a, b, MGUH 19526; paratype pygidium and nine thoracic segments, right lateral and dorsal views. $\times 3$. 3, MGUH 19525; paratype hypostome, ventral stereo-pair view, $\times 10$. 4a, b, MGUH 19520; paratype fragmentary cranidium, left lateral and dorsal views, $\times$ 4. 5, MGUH 19529; paratype pygidium, posterior view, $\times$ 4. 6, MGUH 19521; paratype cranidium, dorsal view, $\times$ 4. 7, MGUH 19524; paratype left free cheek, plan view, $\times 4$. 8a-d, MGUH 19518; paratype cephalon, left lateral, oblique anterior, anteroventral and dorsal views, $\times 4$. 9, MGUH 19522; paratype cranidium, dorsal view, $\times 4$. 

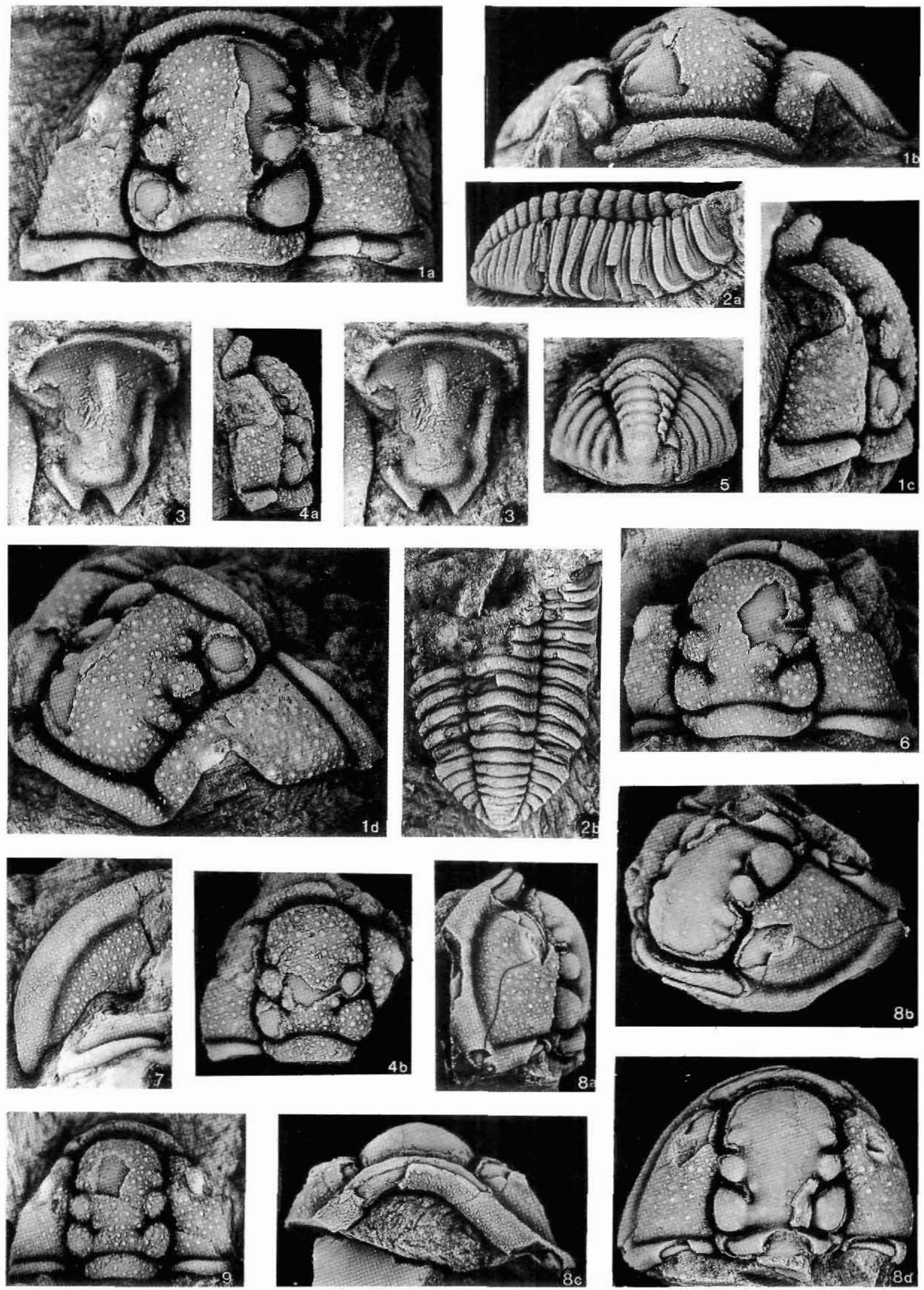
which turns sharply over to descend in a short, slightly forwardly-projecting and moderately strongly convex arc to rostral suture. Anterior border is relatively low and reaches dorsally about one-half to two-thirds up the anterior face of the frontal glabellar lobe. Opposite abaxial part of axial furrow and innermost part of fixed cheek the anterior border is longer (exsag.) than it is sagittally; between innermost part of fixed cheek and anterior branch of facial suture it narrows (exsag.) sharply and descends steeply.

Posterior border is tightly convex (exsag.) and expands slightly in length (exsag.) between axial furrow and fulcrum; farther abaxially, it is slightly less convex and widens gradually to a point near genal angle where posterior margin and border furrow become more parallel because of the slight forward flexure of the posterior margin. Posterior border furrow is narrow, moderately deep to deep and V-shaped in profile (exsag. ); it meets posterior section of lateral border furrow on fixed cheek just before facial suture. Posterior part of fixed cheek is long and in profile (exsag.) it is flat to very gently dorsally convex between palpebral lobe and border furrow; abaxially it slopes steeply to facial suture. Anterior part of fixed cheek is about as wide as L2; its inner anterior corner is slightly angular and weakly overhangs the border furrow. Palpebral lobe is about as long as L2 and narrow (tr.); it rises moderately steeply from fixed cheek and its abaxial margin is slightly pointed at its mid-length which lies opposite (tr.) L3. Width of cranidium at posterior margin of palpebral lobe is 1.65-1.7 times glabellar width at L2. Posterior branch of facial suture runs slightly backward for a short distance before turning sharply backward; farther on, at a point just before lateral border furrow, it turns more adaxially onto lateral border; thereafter it runs exsagittally before finally bending slightly outward again to bisect genal angle. Anterior branch runs slightly inward to border furrow, then it turns sharply inward across anterior face of anterior border to meet rostral suture. Free cheek bears a narrow eye socle; main field is moderately convex; border furrow is U-shaped; border is generally wide but narrows near genal angle; it is strongly convex adjacent to anterior branch of facial suture though less so posteriorly.

Rostral plate comprises border and doublure sectors. Border sector is about 4.9 times as wide (tr.) as long (sag.). Rostral and hypostomal sutures are broadly arched; connective suture is slightly convex abaxially and it trends strongly inward and downward from the junction of the facial and rostral sutures. Anterior border of hypostome is strongly reflexed ventrally; anterior border furrow is marked by a break in slope between anterior border and anterior lobe of middle body. Ante- rior wing moderately large, with a dorsally directed pit. Lateral border is narrow and tightly convex (tr.); lateral border furrow is best marked anteriorly. Posterior margin is bifid, with two small to moderately large flat spines which are delimited from the middle body by a well-marked posterior border furrow. Medially, posterior border is extremely short (sag.). Anterior lobe of middle body is about 2.5 times as long (sag.) as the posterior lobe; it bears a strongly ventrally-projecting median protuberance. Posterior lobe falls steeply posteriorly (sag.) to border furrow, slightly less so abaxially to lateral shoulder. Macula is at most extremely weakly differentiated, sited in a sunken suboval area; median furrow is present only laterally, leading anteriorly and slightly abaxially from suboval area to meet anterior part of lateral border furrow.

Thorax has at least 11 segments; axis is weakly to moderately arched (tr.). Axial ring is flat to gently convex in profile (sag.), lengthens (exsag.) slightly at the axial furrow where it is weakly produced forward and has a subrounded outer, anterior margin. Articulating furrow is U-shaped, sagittally it is one-quarter to one-third the length of the axial ring and it becomes narrower at the axial furrow. Articulating half-ring is slightly shorter than axial ring and gently convex (sag.). Pleural furrow is sharply incised; it narrows gradually abaxially where it runs slightly forward onto pleural facet before turning backward slightly to die out. Posterior pleural band is moderately to strongly convex (exsag.), it narrows gradually abaxially to form a bounding rim to the articulating facet; anterior pleural band is lower and shorter. Fulcrum is at a distance (tr.) from the axial furrow which varies, from the posterior to the anterior part of thorax, from about 0.15 to 0.3 times the axial width.

Pygidium is about 1.6 times as wide as long. Axis of seven or eight rings is about 0.45 times as wide as pygidium; it is moderately convex anteriorly and more

\section{Plate 2}

All specimens from GGU sample 301925, Kap Tyson, Hall Land, western North Greenland.

Calymene iladon sp. nov.

Figs 1a-e, MGUH 19519; paratype cephalon, dorsal stereopair, right lateral, frontal, left lateral and right lateral oblique views. $\times$ 4. 2a-d, MGUH 19530; paratype pygidium, posterior stereo-pair, dorsal, right lateral and right lateral oblique views, $\times$ 4. 3a-c, MGUH 19527; paratype pygidium and seven articulated thoracic segments, dorsal, posterior and left lateral views, $\times$ 3. 4a-c, MGUH 19528; paratype pygidium and two articulated thoracic segments, right lateral, dorsal and right lateral oblique views, $\times 3$. 5a, b, MGUH 19523; paratype cranidium, left lateral oblique and dorsal views, $\times 4$. 

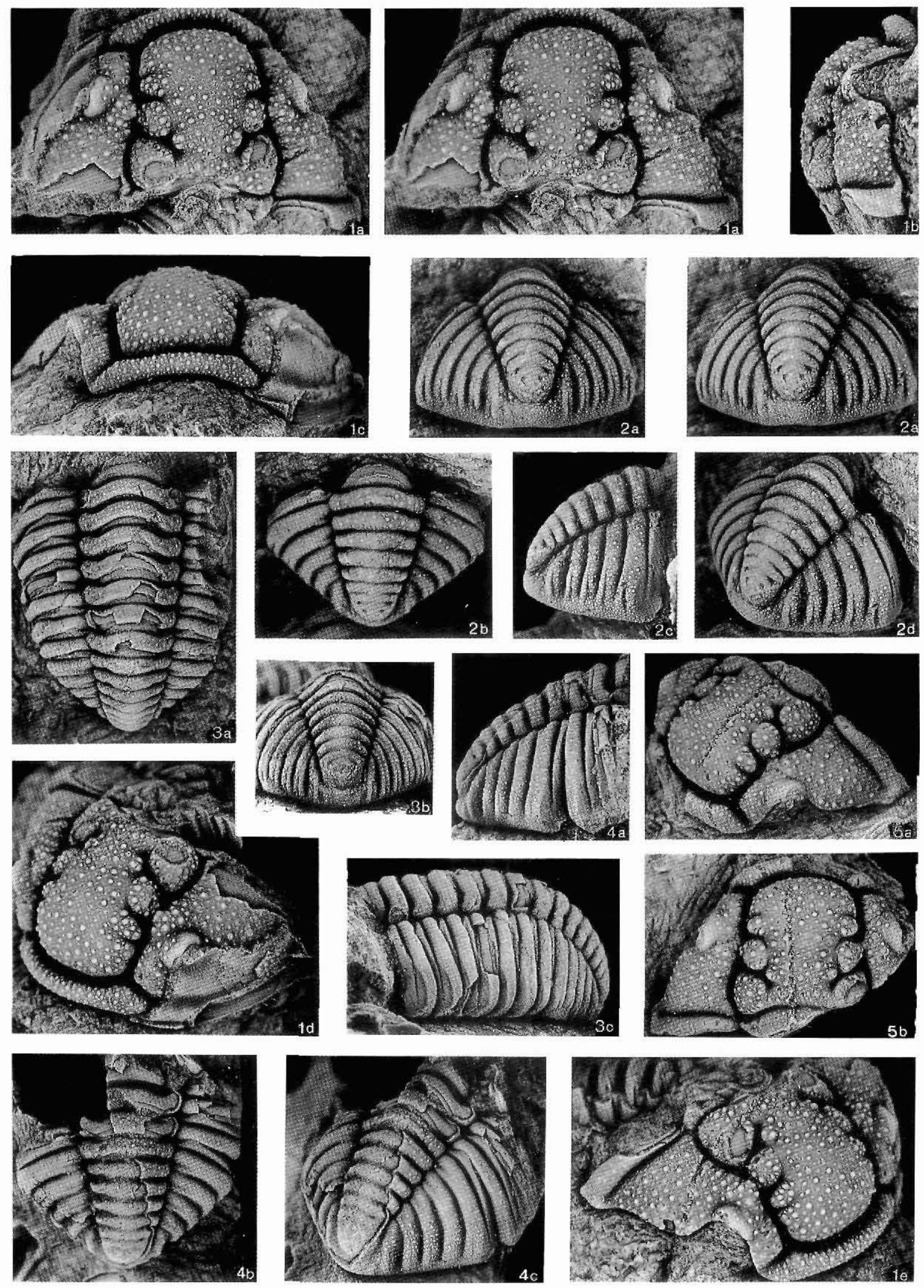
so posteriorly where its sides descend more steeply to the axial furrow. Inter-ring furrows are mostly best marked abaxially and shallowest medially, and the eighth (and sometimes seventh) are isolated from the axial furrow. Small terminal piece falls steeply to postaxial sector. Axial furrow is well marked, weakest anteriorly and becomes progressively better incised posteriorly; behind postaxial sector it becomes more diffuse again. Pleural region slopes strongly for a short distance to the fulcrum, thereafter very strongly to lateral margin where it rolls tightly under to doublure. Fulcrum very close to axial furrow. First pleural furrow runs onto articulating facet. There are at least five well incised pleural furrows which are weakest adjacent to the axial furrow; they become deeper and slightly wider at midlength before narrowing and ending close to the lateral margin. Interpleural furrows are relatively weak at axial furrow, more abaxially very weak or absent, becoming better defined distally. Anterior pleural band of sixth pleura forms weakly posteriorly projecting side to postaxial sector; short, weak sixth pleural furrow is sometimes present.

Sculpture on dorsal surface of cranidium and main field of free cheek is of very small to large granules which are very sparse and very small on most dorsal parts of sides of cranidial furrows. Very loosely scattered, small granules are present in the lateral border furrow; medium, rather uniformly sized, closely distributed granules occur on lateral border and border sector of rostral plate. Very small granules are present on middle body and borders of hypostome. Small to large sized granules occur on all axial rings and inner pleural region where they are more loosely scattered. Outer part of pygidial pleural region, postaxial sector and border roll have medium sized closely packed granules. Granules are absent from deeper parts of axial, ring, pleural and interpleural furrows.

Discussion. The combination of features given in the diagnosis immediately differentiates this new Calymene species, but the very forwardly placed palpebral lobe and, apparently, the nature of the maculae, are the most important distinguishing characters. The only hypostomes recovered are small or indifferently preserved in the area of the maculae, but at most this feature seems to be extremely weakly discriminated and is sited in a sunken suboval area.

Previously described Silurian calymenids from Greenland, or from northern or Arctic Canada - areas which show trilobite faunal links with Greenland at this time - are represented by sparse and generally poorly preserved specimens. The calymenid described here represents by far the most complete known from the
Silurian of these areas. There are only two other records of Calymene from Greenland, both of which refer to unnamed species. The Calymene sp. of Lane (1972, pl. 64 , figs 6,7 ) from late Llandovery or early Wenlock strata of Kronprins Christian Land differs in its subparallel-sided, more strongly sagittally convex glabella; its shorter preglabellar area, the very short anterior border of which is scarcely visible in dorsal view; and its more posteriorly positioned palpebral lobe, the mid-length of which lies opposite the anterior part or margin of lobe $2 p$. On the cranidia of the Kronprins Christian Land Calymene, which are largely internal moulds, there is in addition the suggestion of a very weak $5 p$ lateral glabellar lobe (Lane, 1972, p. 359).

The former distinctions also apply to the Calymene sp. of Norford (1981; it is not referable to Flexicalymene - Derek J. Siveter \& B. D. E. Chatterton, unpublished information) from the late Llandovery or early Wenlock of Hudson Bay, Canada, which incidentally at least very closely resembles the Calymene sp. of Lane, 1972.

Calymene sp. of Lane (1984, pl. 2, fig. 10) also from Hall Land in rocks of probable Wenlock age is represented by a single cranidium which is less complete than Lane's (1972) material, but so far as can be judged, the two sets of material also represent similar if not the same species. This latter cranidium can still be distinguished from $C$. iladon by having the mid-length of the palpebral lobe transversely opposite the anterior margin of the $\mathrm{L} 2$.

The buttressing of the fixed cheek opposite the L3 in the calymenid cranidia described as Calymene sp. by Perry \& Chatterton (1977, pl. 4, figs 19-21) from the Wenlock of the Canadian Arctic, readily separates this material from $C$. iladon. Of figured Canadian Silurian calymenids, one of the most similar to $C$. iladon is the single cranidium referred to $C$. breviceps Raymond by Ludvigsen $(1979$, p. 68, fig. 45 , E) from the late Wenlock (see Berry \& Boucot, 1970, p. 115) Eramosa Formation of southern Ontario. This cranidium, however, does not belong to breviceps (for instance its preglabellar area, though relatively short, is still much longer (sag.) than that of the American taxon in which it is exceptionally short; see Whittington, 1971, pl. 83, figs 1,2 ), but it does not precisely agree with $C$. iladon either, as its palpebral lobe does not appear to be so forwardly placed.

Of named Calymene species, $C$. frontosa Lindström, 1885 , known from the late Llandovery to early Wenlock in the Baltic, Scandinavia and Scotland, shows similarity to $C$. iladon in its continuously narrow cranidial posterior border furrow. This is a relatively unusual feature in species of the genus, but many other features separate $C$. frontosa, including its longer preglabellar 
area, higher anterior border and deeper preglabellar furrow, and the strongly subconical and overhanging anterior corner of its fixed cheek (Männil, 1977, pl. 2, fig. 1). C. chica Šnajdr (1982, pl. 2, fig. 1) from the Prídolí of Czechoslovakia is not too dissimilar from $C$. iladon, but in the Bohemian form the palpebral lobe is more posteriorly positioned (Siveter, 1989, p. 132, has further discussion).

Acknowledgements. We thank Dr John S. Peel for bringing the material to our attention and arranging for its loan. Dr Alan Thomas suggested improvements to the typescript for which we are grateful.

\section{References}

Berry, W. B. N. \& Boucot, A. J. 1970: Correlation of the North American Silurian rocks. Spec. Pap. geol. Soc. Amer. 102, 289 pp.

Brongniart, A. \& Desmarest, A. G. 1822: Histoire naturelle des crustacés fossiles sous les rapports zoologiques et géologiques. Savoir: Les Trilobites. Paris. 154 pp.

Chang Wen-Tang 1974: [Silurian Trilobita] 173-187, pls 80-85. In Nanking Institute of Geology and Palaeontology (ed.) [A handbook of the stratigraphy and palaeontology in southwest China]. Beijing: Science Press. Academia Sinica. [In Chinese.]

Chatterton, B. D. E. \& Campbell, K. S. W. 1980: Silurian trilobites from near Canberra and some related forms from the Yass Basin. Palaeontographica A 167, 77-119, pls 1-16.

Chatterton, B. D. E. \& Ludvigsen, R. 1976: Silicified Middle Ordovician trilobites from the South Nahanni River area, District of Mackenzie, Canada. Palaeontographica A 154, 106 pp., 22 pls.

Dawes, P. R. \& Peel, J. S. 1984: Biostratigraphic reconnaissance in the Lower Palaeozoic of western North Greenland. Rapp. Grønlands geol. Unders. 121, 19-51.

Desmarest, A. G. 1817: In Nouveau Dictionnaire d'Histoire naturelle (2nd edn.) 8, 517-518.

Etheridge, R. \& Mitchell, J. 1890: On the identity of Bronteus partschi, de Koninck (non Barrande), from the Upper Silurian rocks of New South Wales. Proc. Linn. Soc. N.S.W. 5, 501-504.

Howells, Y. 1982: Scottish Silurian trilobites. Monogr. palaeontogr. Soc. [London]. 76 pp., pls 1-15 (Publ. No. 561, part of Vol. 135 for 1982).

Hurst, J. M. 1980: Silurian stratigraphy and facies distribution in Washington Land and western Hall Land, North Greenland. Bull. Grønlands geol. Unders. 138, 95 pp.

Kobayashi, T. \& Hamada, T. 1974: Silurian trilobites of Japan in comparison with Asian, Pacific and other faunas. Spec. Pap. pal. Soc. Japan 18, 155 pp.

Kobayashi, T. \& Hamada, T. 1986: The second addition to the Silurian trilobite fauna of Yokokura-yama, Shikoku, Japan. Trans. Proc. pal. Soc. Japan 143, 447-462.
Kobayashi, T. \& Hamada, T. 1987: On the Silurian trilobite faunule of Hitoegane near Fukuji in the Hida Plateau, Japan. Trans. Proc. pal. Soc. Japan 147, 131-145.

Lane, P. D. 1972: New trilobites from the Silurian of north-east Greenland, with a note on trilobite faunas in pure limestones. Palaeontology 15, 336-364.

Lane, P. D. 1979: Llandovery trilobites from Washington Land, north Greenland. Bull. Grønlands geol. Unders. 131, $37 \mathrm{pp}$.

Lane, P. D. 1984: Silurian trilobites from Hall Land and Nyeboe Land, western North Greenland. Rapp. Gronlands geol. Unders. 121, 53-75.

Lane, P. D. 1988: Silurian trilobites from Peary Land, central North Greenland. Rapp.Grønlands geol. Unders. 137, 93117.

Lane, P. D. \& Owens, R. M. 1982: Silurian trilobites from Kap Schuchert, Washington Land, western North Greenland. Rapp. Grønlands geol. Unders. 107, 41-69.

Lane, P. D. \& Peel, J. S. 1980: Trilobites and gastropods from Silurian carbonate mounds in Valdemar Glückstadt Land, eastern North Greenland. Bull. Grønlands geol. Unders. 101, 54 only.

Lane, P. D. \& Thomas, A. T. 1978: Family Scutelluidae. In Thomas, A. T., British Wenlock trilobites. Part 1. Monogr. palaeontogr. Soc. [London]. 56 pp., pls 1-14 (Publ. No. 552, part of Vol. 132 for 1978).

Lane, P. D. \& Thomas, A. T. 1983: A review of the trilobite suborder Scutelluina. In Briggs, D. E. G. \& Lane, P. D. (ed.) Trilobites and other early arthropods: papers in honour of Professor H. B. Whittington, FRS. Spec. Pap. Palaeont. 30, 141-160.

Lane, P. D., Dawes, P. R. \& Peel, J. S. 1980: A new Silurian Hemiarges (Trilobita) from North Greenland and the question of the Polaris Harbour Formation. Rapp.Grønlands geol. Unders. 101, 45-53.

Lindström, G. 1885: Forteckning på Gotlands siluriska crustaceer. Ofvers K. VetenskAkad. Forh. 6, 37-100, pls 12-16.

Ludvigsen, R. 1979: Fossils of Ontario. Part 1: The Trilobites. Royal Ontario Museum Life Sciences Miscellaneous Publications. 96 pp.

Männil, R. 1977: East Baltic Lower Silurian Calymenidae (Trilobita). In Kaljo, D. (ed.) Facies and fauna of the Baltic Silurian. Akad. Nauk Eston. SSR. Inst. Geol. Tallinn, 240285. [In Russian with English and Estonian summaries.]

Milne Edwards, H. 1840: Histoire naturelle des Crustaces, comprenant l'anatomie, la physiologie et la classification de ces animaux 3, 638 pp. Paris.

Murchison, R. I. 1839: The Silurian System. xxxii +768 pp., 37 pls. London: John Murray.

Norford, B. S. 1981: The trilobite fauna of the Silurian Attawapiskat Formation, northern Ontario and northern Manitoba. Bull. geol. Surv. Canada 327, 37 pp.

Perry, D. G. \& Chatterton, B. D. E. 1977: Silurian (Wenlockian) trilobites from Baillie-Hamilton Island, Canadian Arctic Archipelago. Can. J. Earth Sci. 14, 285-317.

Perry, D. G. \& Chatterton, B. D. E. 1979: Wenlock trilobites and brachiopods from the Mackenzie Mountains, northwestern Canada. Palaeontology 22, 569-607. 
Přibyl, A. \& Vaněk, J. 1971: Studie uber die Familie Scutelluida Richter et Richter (Trilobita) und ihre phylogenetische Entwicklung. Acta Univ. Carolinae Geol. 4, 361-394.

Siveter, D. J. 1989: Silurian trilobites from the Annascaul Inlier, Dingle Peninsula, Ireland. Palaeontology 32, 109161.

Šnajdr, M. 1958: Několik nových rodủ trilobitủ z čeledě Scutelluidae. Vest. Ústred. úst. geol. 33, 177-184.

Snajdr, M. 1960: Studie o čeledi Scutelluidae (Trilobitae). Rozpr. Ústred. úst. geol. 26, 11-221. [English summary, 227-265.]

Šnajdr, M. 1982: Bohemian Silurian and Devonian Calymenidae (Trilobita). Cas. Miner. Geol. 27, 371-378.

Vogdes, A. W. 1890: A bibliography of Palaeozoic Crustacea from 1698 to 1889 , including a list of North American species and a systematic arrangement of genera. Bull. U.S. geol. Surv. 63, 177 pp.

Whiteaves, J. F. 1904: Preliminary list of fossils from the Silurian (Upper Silurian) rocks of the Ekwan River, and Sutton Mill Lakes, Keewatin, collected by D. B. Dowling in 1901, with descriptions of such species as appear to be new. Ann. Rep. geol. Surv. Canada 14, 38F-59F.

Whittington, H. B. 1971: Silurian calymenid trilobites from the United States, Norway and Sweden. Palaeontology 14, 455477.

Zhou Zhi-qiang \& Chen Run-ye 1975: Trilobita. In Li Yao-xi, Song Li-sheng, Zhou Zhi-qiang \& Yang Jing-yao (ed.) [Early Palaeozoic stratigraphy in the western part of the Dabashan mountains]. Beijing: Earth Science Publishing House, $372 \mathrm{pp}, 70 \mathrm{pls}$. 